\title{
Abstracts
}

These abstracts have been specially commissioned for this Journal. Many of the titles have been taken from Abstracts of World Medicine and Ophthalmic Literature, published by the British Medical Association, and the references to these sources are given. The subjects are arranged in the following sub-sections:

Rheumatic Fever
Rheumatoid Arthritis
Still's Disease
Osteoarthrosis
Spondylitis
Gout

Other Forms of Arthritis
Bone Diseases
Non-articular Rheumatism, including Disc
Syndromes, Sciatica, etc.
Connective Tissue Studies
Pararheumatic (Collagen) Diseases

Immunology and Serology Biochemical Studies Therapy Surgery Other General Subjects

Not all sections may be represented in any one issue.

\section{Rheumatic fever}

Incidence and Clinical Manifestations of Cerebral Lesions in Rheumatic Fever (In Russian) Yasinovskî, M. A., and Rosentsvaig, A. M. (1970) Klin. Med. (Mosk.), 48, No. 8, p. 1485 figs, 34 refs

(Abstr. Wld Med. (1970) 45, 39)

Contrasting Epidemiology of Acute Rheumatic Fever and Acute Glomerulonephritis. Nature of the Antecedent Streptococcal Infection Bisno, A. L., Pearce, I. A., Wall, H. P., Moody, M. D., and Stollerman, C. H. (1970) New Engl. J. Med., 283, 5613 figs, 23 refs

(Abstr. Wld Med. (1970) 45, 61)

Clinical and Statistical Observations on 872 Cases of Rheumatic Fever (Osservazioni clinico statistiche su 872 casi di malattia reumatica) CoRso, D., Vassallo, F., and ZıIno, L. (1970) Pediatria (Napoli), 78, 5057 figs, 42 refs

Acute Articular Rheumatism. Manifestations of Rheumatic Fever in Relation to Diagnosis and Treatment (Akuter Gelenkrheumatismus - die Pathomorphose des rheumatischen Fiebers im Hinblick auf Diagnostik und Therapie) Graser, F. (1970) Praxis, 59, 13813 figs, 23 refs

Notching of the QRS Complex in High Frequency Electrocardiograms of Normal Children and in Children with Rheumatic Fever HolCROFT, J. W., and LIEBMAN, J. (1970) J. Electrocardiol., 3, 1338 figs, 41 refs

Rheumatic Heart Disease Epidemiology. II. Colorado's High-Risk Low-Socioeconomic Region in 1960 MORTON, W. E., and LichtY, J. A. (1970) Amer. J. Epidem., 92, 113 13 refs

\section{Rheumatoid arthritis}

Familial Concurrence of Myasthenia Gravis and Rheumatoid Arthritis NAMBA, T., and GROB, D. (1970) Arch. intern. Med., 125, 105620 refs

This paper describes a brother and sister seen at the
Department of Medicine of the State University of New York. Both patients had rheumatoid arthritis and died of myasthenia gravis. Rheumatoid arthritis was diagnosed in the brother at the age of 52 years and treated with prednisolone and corticotrophin; 6 months later he developed fatigue, ptosis, and weakness which responded to treatment with anticholinesterases. He continued to work to the age of 58, but thereafter his myasthenic symptoms increased. His clinical state shortly before his death at age 61 is recorded, together with the findings at a post mortem examination. The sister developed myasthenia at age 29 and rheumatoid arthritis at age 40; the myasthenia initially responded to neostigmine, but subsequently became resistant and there was no improvement after thymectomy. She died at the age of 44 years and a post mortem is reported. In the family a brother had a history suggestive of myasthenia, a second brother had rheumatoid arthritis, and two other siblings had neither disease.

The familial occurrence of each disease is discussed and the relevant literature cited. The results of serological tests in these two conditions are evaluated.

A. J. PALFREY

Adjuvant-Activity of 'Diphtheroid' Organisms isolated from the Joints of Cases of Rheumatoid Arthritis WHITE, R. G., and Gordon, J. (1970) Clin. exp. Immunol., 7, 139 3 figs, 14 refs

This paper, from the University of Glasgow, attempts to characterize in some detail organisms isolated from the joints of rheumatoid arthritics. Two selected isolates from fourteen Löwenstein-Jensen cultures were studied. The organisms isolated were shert, non-motile, Gram-positive rods, weakly acid-fast, non-spore-bearing, and facultatively anaerobic. They did not produce acid or clot in litmus milk, nor ferment a range of sugars, liquefy gelatin, or hydrolyse starch. Electron microscopy revealed a surface network of filaments $125 \AA$ wide. Similar, but slightly wider, filaments are seen in strains of Mycobacterium tuberculosis.

Investigation of the isolated organisms for adjuvant activity in guinea-pigs showed that both isolates induced delayed hypersensitivity to ovalbumin and increased 
serum precipitin and complement-fixing antibodies to ovalbumin compared to controls.

The authors conclude that these organisms show an adjuvant effect very similar to that shown by the peptidoglycolipid components of mycobacteria, and indicate their belief that substances with immunological adjuvant activity may be concerned in the pathogenesis of rheumatoid arthritis.

J. R. DALY

Gastro-intestinal Disturbances in Patients with Severe Rheumatoid Arthritis Pettersson, T., Wegelius, O., and Skrifvars, B. (1970) Acta med. scand., 188, 139 1 fig., 15 refs

In this study from Helsinki and Heinola, Finland, 22 patients with classical rheumatoid arthritis and two with ankylosing spondylitis were investigated for intestinal malabsorption. Liver function was investigated in nineteen of the 24 patients and pancreatic function in five.

Fourteen patients had normal lactose and glucosegalactose tolerance curves. In the remaining ten the lactose tolerance curve was abnormally flat while the glucose-galactose curve was normal. Intestinal biopsy material showed no mucosal atrophy but perivascular amyloidosis was seen in four patients. Reduced lactase concentration was found in biopsy specimens from six patients. The d-xylose test was abnormal in seven of the 24 patients and absorption of vitamin A impaired in nine.

Five patients had one or more abnormal tests of liver function and one had reduced pancreatic function.

The authors stressed that lactose intolerance is not infrequent in the Finnish population. However, in two patients the lactose tolerance curve became normal when the rheumatoid arthritis reached a more quiescent stage. The same two patients also had abnormal liver function tests which became normal when the disease went into remission. In many cases the disturbances of gastrointestinal and liver function tended to improve during treatment of the rheumatoid disease and it was suggested that these disturbances are related to the disease process rather than to therapy.

D. A. PITKEATHLY

Rheumatoid Arthritis and Diabetes Mellitus (Primär chronische Polyarthritis und Diabetes mellitus) WEIGL, E. (1970) Z. ges. inn. Med., 25, 6211 fig., 46 refs (Abstr. Wld Med. (1970) 45, 39)

Histological Investigation of the Gastric Mucosa in Rheumatoid Arthritis (Histologische Untersuchungen der Magenschleimhaut bei Rheumatoider Arthritis) FENYÖHÁZI, L., WALACHER, L., and MEDGYES, Á. (1970) $Z$. Rheumaforsch., 29, 1535 figs, 24 refs

(Abstr. Wld Med. (1970), 45, 40)

Early Diagnosis of Rheumatoid Arthritis (Le diagnostic précoce de la polyarthrite rhumatoïde) FALLET, G. H. (1970) Schweiz. med. Wschr., 100, 20138 figs
Influence of Treatment on Iron Metabolism in Patients with Rheumatoid Arthritis (Therapieeinflüsse auf den Eisenstoffwechsel bei Patienten mit progressiv chronischer Polyarthritis) SIERING, H., and ErTNER, K. (1970) Z. ges. inn. Med., 25, 82736 refs

Kidney Changes in Rheumatoid Arthritis (Nierenveränderungen bei progredient chronischer Polyarthritis) Frank, O. (1970) Wien. Z. inn. Med., 51, 39933 refs

Rheumatoid Heart Disease with Complete Heart Block HARris, M. (1970) J. clin. Path., 23, 6233 figs, 12 refs

Radiological Appearances of the Cervical Spine in Rheumatoid Arthritis (Aspects radiologiques de la colonne cervicale dans l'arthrite rhumatoïde) OTT, H., Wettstein, P., Radi, I., and MosimanN, U. (1970) Schweiz. med. Wschr., 100, 1726 6 figs, 7 refs

Abnormalities of the Ribs in Rheumatoid Arthritis [In Dutch] NiEnhuis, R. L. F. (1970) Ned. T. Geneesk., 114, 14813 figs, 12 refs

Amyloidosis in Rheumatoid Arthritis Wolf, E. (1970) Harefuah, 78, 549 (English Summary on p. 579) 15 refs

In vitro Studies on the Pathogenesis of Rheumatoid Arthritis by Means of the Migration Inhibition Test (In vitro-Studie zur Pathogenese der primär-chronischen Polyarthritis mittels des Migrations-Inhibitionstests) Rothenberger, W., and Thiele, H. G. (1970) Klin. Wschr., 48, 13082 figs, 43 refs

Peripheral Vascular Circulation in Patients with Rheumatoid Arthritis. Influence of Papaverine BATTERMAN et. al. (1970) Angiology, 21, 612

Congenital Deformities of Mice transmitted by an Agent from Rheumatoid Synovium WARREN et. al. (1970) Clin. Orthop., 70, 216

\section{Still's disease}

Juvenile Rheumatoid Arthritis: a Serologic Survey of 200 Consecutive Patients Bluestone, R., Goldberg, L. S., Katz, R. M., Marchesano, J. M., and Calabro, J. J. (1970) J. Pediat., 77, 9818 refs

(Abstr. Wld Med. (1970), 45, 39)

Clinical Picture and Course of Juvenile Rheumatoid Arthritis and Still's Disease (Klinisches Bild und Verlauf der juvenilen rheumatoiden Arthritis und des StillSyndroms) KöLLE, G. (1970) Mschr. Kinderheilk., 118, 48813 refs

(Abstr. Wld Med. (1970), 45, 40)

Autoantibodies in Juvenile Rheumatoid Arthritis (Autoanticuerpos en artritis reumatoidea juvenil) MORTzO, O. G., HUBSChER, O., and ARANA, R. M. (1970) Medicina (B. Aires), 30, 38421 refs 


\section{Osteoarthrosis}

Rapidly Destructive Osteoarthrosis of the Hip (La coxarthrose destructrice rapide) LEQUESNE, M., and Amouroux, J., (1970) Presse méd., 78, 14353 figs (Abstr. Wld Med. (1970), 45, 43)

Osteoarthrosis: Biology and Principles of Treatment MACHTEY, I. (1970) Harefuah, 78, 541 (English Summary on p. 579) 6 figs, 20 refs

Osteoarthrosis in the Elderly and Possibilities of its Treatment (Die Arthrosis deformans beim alten Menschen und ihre Behandlungsmöglichkeiten) CoTTA, H. (1970) Dtsch. med. J., 21, 1096

New Haven Survey of Joint Diseases. XI: Observer Variability in the Assessment of $\mathrm{X}$-rays for Osteoarthrosis of the Hands WRIGHT, E. C., and ACHESON, R. M. (1970) Amer. J. Epidem., 91, 3786 figs, 20 refs

\section{Spondylitis}

Disturbed Oesophageal Manometric Responses in Patients with Ankylosing Spondylitis and Pulmonary Aspergilloma Scobie, B. A. (1970) Aust. Ann. Med., 19, 1314 figs, 12 refs

Two cases of ankylosing spondylitis are described in which there was evidence of pulmonary mycetomas. Oesophageal manometry showed defective peristalsis in the oesophagus and that the gastro-oesophageal sphincter failed to relax on swallowing. It is suggested that these may be the cause of the pulmonary complications which have been described in ankylosing spondylitis. A. MYLES

Thermography of the Spine and Sacro-iliac Joints in Spondylitis Agarwal, A., LloYd, K. N., and Dovey, P. (1970) Rheum. phys. Med., 10, 3496 figs, 17 refs (Abstr. Wld Med. (1970), 45, 42)

Expanding Lesion of the Intervertebral Disc in a Case of Ankylosing Spondylitis BACHYNSKI, J. E. (1970) J. Canad. Ass. Radiol., 21, 1104 figs, 6 refs

Destruction of the Odontoid Process due to Atlanto-Axial Pyogenic Spondylitis AHLBÄCK and COLLERT (1970) Acta radiol. Diagn., 10, 394

\section{Gout}

Uric Acid Lithiasis-A Study of 622 Patients Frank, M., LAZEBNIK, J., and VRIES A. DE (1970) Urol. int. (Basel), 25, 32

This paper describes 622 patients with uric acid lithiasis seen over a 12-year period, representing one-third of the total number of patients seen with stones.

Urate stone secondary to myeloproliferative disorders represented a very small group, 0.5 per cent. Of the rest, 20 per cent. showed associated gouty arthritis, the 80 per cent. remaining constituting an idiopathic group. During the follow-up (16 mths to 12 yrs) $3 \cdot 1$ per cent. of patients in the idiopathic group developed gout. The idiopathic group showed a much lower male : female ratio $(2 \cdot 7: 1$ compared to $12 \cdot 3: 1)$ and an earlier age at onset. Both groups showed a preponderance of those of European stock compared with those of Near-Eastern origin.

In the idiopathic group mild hyperuricaemia was observed in 23.9 per cent. of males and 10.9 per cent. of females and there was a tendency for the plasma uric acid level to rise during the follow-up period. The percentage of patients in this group who were hyperuricaemic also rose from 19 to 33 per cent. during the follow-up period.

Hyperuricosuria (more than $800 \mathrm{mg}$./day) was surprisingly seen in only 30 per cent. of both the gouty and the idiopathic groups.

The most surprising finding was that, in both the gouty and idiopathic groups, there was a high incidence of hyperparathyroidism $(3 \cdot 1$ per cent. of histologicallyproven cases and $7 \cdot 3$ per cent. clinically-diagnosed cases), a total of 10.4 per cent.

Conversely, in a personal series of 148 cases of hyperparathyroidism (97 proven surgically; 47 clinically suspect; 3 post mortem), 34 (22.9 per cent.) had uric acid lithiasis. The nature of this association between uric acid lithiasis and hyperparathyroidism remains obscure.

R. GRAHAME

Influence of Hypertonic Saline Infusions upon the Fractional Reabsorption of Urate and Other Ions in Normal and Hypertensive Man Cannon, P. J., Svahn, D. S., and Demartini, F. E. (1970) Circulation, 41, 97

Studies of a possible inter-relationship between sodium and urate excretion have not been previously carried out, but such a relation is suggested by the facts that diminished urate excretion is said to accompany reduced sodium output during low salt diets, and that excretion rates of sodium and urate rise together in advanced uraemia.

Short-term renal clearance studies were performed on 24 normotensive and hypertensive patients before and during expansion of the extracellular fluid volume by intravenous infusion of hypertonic $(2.5$ per cent.) saline. Arterial blood pressure did not change; glomerular filtration rate rose; renal vascular resistance fell; and the rise in excretion of sodium was accompanied by a directly related rise in that of urate, as well as that of calcium, magnesium, potassium, and chloride. The nonspecificity of this depressed fractional ion reabsorption was considered to be compatible with the idea that increased hydrostatic pressure (or diminished colloid osmetic pressure) in peritubular capillaries may retard the net reabsorption of a number of ions other than sodium and water; or alternatively that a natriuretic hormone induces a generalized depression of tubular reabsorptive capacity.

(The data from this study refer only to overall handling of urate by the kidney, and take no account of the possible separate roles of filtration, reabsorption and active tubular secretion).

J. T. SCOTT

Liver Involvement in Gout HeNNECKE, A., and SüDhOF, H. (1970) Germ. med. Mth., 15, 395

Clinicopathologic Conference: Hypertension, Hyperuricemia and Iatrogenic Disease Amer. J. Med., 49, 242 Appearance of Chemotactic Activity following Intra- 
articular Injection of Monosodium Urate Crystals: Effect of Colchicine PhelPS, P. (1970) J. Lab. clin. Med., 76, 6224 figs, 16 refs

\section{Other forms of arthritis}

Acute Suppurative Arthritis in Infancy and Childhood Paterson, D. C. (1970) J. Bone Jt Surg., 52-B, 47414 figs, 11 refs

This report from the Department of Orthopaedic Surgery in the Adelaide Children's Hospital concerns 96 patients treated for suppurative arthritis in the years 1960 to 1967.

The hip was the most commonly affected joint (57 out of 96) and Staph. aureus much the commonest organism.

Four principles of treatment were followed:

(1) Immediate arthrotomy to evacuate pus and remove tension;

(2) Complete skin closure without drainage to avoid secondary infection;

(3) Immobilization and plaster for 6 weeks (no traction was used);

(4) Antibiotics, according to sensitivity tests, given for 6 weeks to sterilize the joint and foci in adjacent bone.

Of nine infants less than a year old, only two regained normal joints and the other joints were destroyed. In older children, fifty were treated by the above methods within 5 days of onset and all regained normal function. Four other joints treated in the same way 18 to 42 days after onset gave unsatisfactory results. 33 joints were treated in other ways and fifteen of them were destroyed. Eleven arthrotomies were performed unnecessarily, in that no sepsis was found, but there were no ill-effects.

The importance of early diagnosis and treatment is stressed, and also the difficulty of diagnosis in infants, which leads to late treatment and poor results.

M. R. JEFFREY

The Ankle Arthrogram Callaghan, J. E., Percy, E. C., and Hill, R. O. (1970) J. Canad. Ass. Radiol., 21, 7413 figs, 15 refs

Articular Manifestations of Haemochromatosis (À propos des maifestations articulaires de l'hémochromatose) Graber-DuVernay, J., and Graber-DuVernay, B. (1970) Rhumatologie, 22, 1934 figs, 62 refs

Clinical and Roentgenologic Study of Knee Joints with Osteophytes Danielsson and Hernborg (1970) Clin. Orthop., 69, 302

\section{Bone disease}

Metabolic Studies with Porcine Calcitonin in Osteoporosis Brown, P., Thin, C. G., Malone, D. N. S., Roscoe, P., and Strong, J. A. (1970) Scot. med. J., 15, 2076 figs, 18 refs

(Abstr. Wld Med. (1970), 45, 20)

Biological Background of Aseptic Necrosis of the Femoral Head in the Adult. Pathogenetic Deductions (Le terrain biologique de l'ostéonécrose aseptique de la tête femorale chez l'adulte. Déductions pathogéniques) LOUYOT, P., and GaUCHer, A. (1970) Rhumatologie, 22, 2111 fig., 57 refs
Non-articular rheumatism

Frozen Shoulder. Passive Exercises for Treatment Liebolt, F. L. (1970) N.Y. St. J. Med., 70, 2085

Anterior Cervical Fusion for Cervical Rhizopathies LiNDBERG (1970) Acta orthop. scand., 41, 312

Protruded Lumbar Intervertebral Discs, with Special Reference to Surgical Technique and Preoperative and Postoperative Management: A Clinical Essay Moyes (1970) Canad. J. Surg., 13, 382

\section{Connective tissue studies}

Collagenolytic Activity in Synovial Fluid Cells in Rheumatoid Arthritis Wegelius, O., Klockars, M., and Vainio, K. (1970) Ann. clin. Res., 2, 17116 refs

This study from the University of Helsinki and the Rheumatism Foundation Hospital, Heinola, Finland, involved six cases of classical rheumatoid arthritis in all of which the collagenolytic activity of the synovial fluid cells was compared to that of a comparable number of buffy coat cells from the blood of the same individuals. The substrate consisted of a gell of acid-soluble collagen obtained from rat-tail tendon which had been labelled with radioactive proline as a precursor. Digestion of the substrate at $\mathrm{pH} 7 \cdot 6$ was assessed by scintillation counting of the solubilized material.

The result in all six cases showed a clear-cut difference between the cells of the synovial fluid and those of the buffy coat. The latter showed no significant collagenase activity, whereas that of the former corresponded to $1 \mu \mathrm{g} . / \mathrm{ml}$. commercial collagenase.

The authors attribute this activity to the polymorphonuclear cells but, in view of the collagenolytic activity of rheumatoid synovial membrane, such a conclusion is unwarranted until the presence of desquamated lining cells has been excluded.

L. E. GLYNN

Giant Cells, Cartilage, and Bone Fragments within Rheumatoid Synovial Membrane: Clinico-Pathological Correlations Muirden, K. D. (1970) Aust. Ann. Med., 19, 1057 figs, 15 refs

An account, from the Department of Medicine of the University of Melbourne, of the histological changes in the synovial membrane in rheumatoid arthritis, as seen in 100 joint biopsies in 81 patients. The clinical features of the patients, the results of laboratory and radiological investigation, and the histological techniques used were described in an earlier paper (Muirden (1970) Aust. Ann. Med., 19, 97).

The synovial changes described-proliferation of synovial lining cells, infiltration with lymphocytes and plasma cells, changes in small blood vessels-are regarded as characteristic of rheumatoid arthritis, but not specific. Attention is directed to two features of rheumatoid arthritis described by Sokoloff (in 'Arthritis and Allied Conditions', ed. J. L. Hollander, 7th ed., Lea and Febiger, Philadelphia), namely the occurrence of distinctive multinucleate giant cells, and the presence of fragments of bone and cartilage in the synovial membrane.

Rheumatoid giant cells (in contrast to giant cells of 
foreign body type) were found in 36 of the 100 biopsies. They are relatively small cells, with basophilic cytoplasm and peripherally-placed nuclei, and are usually near the synovial surface. Some give a positive reaction for iron, as do the adjacent synovial cells.

Fragments of bone or cartilage were present in 56 of the 100 biopsies. They appeared to originate from erosive lesions involving the articular cartilage and adjacent bone, and not as a result of synovial metaplasia.

Rheumatoid giant cells, and fragments of bone and cartilage occur in joints showing relatively advanced disease as judged by $x$-ray changes. The presence of fragments of cartilage and bone shows a significant correlation with the duration of the joint disease, and with the presence of anaemia, but not with the titre of rheumatoid factor.

H. A. SISSONS

Value of Synovial Cytology in the Diagnosis of Isolated Hydrarthroses of the Knee (Intérêt de la cytologie synoviale dans le diagnostic des hydarthroses isolées du genou) Gras, J.-P., Phélip, X., Verdier, J.-M., and Cabanel, G. (1970) Rhumatologie, 22, 2035 figs

Hormonal Influences on Collagen Turnover. Effect of Prednisolone and Methylandrostenolone in the Healthy Rat(Hormonelle Beeinflussung des Kollagenstoffwechsels: Wirkung von Prednisolon und Methylandrostenolon bei der gesunden Ratte) RUIZ-Torres, A. (1970) $Z$. Rheumaforsch., 29, 2694 figs, 21 refs

Involvement of Articular Cartilage in a Linear Relaxation Process during Walking YanNAS, I. V. (1970) Nature (Lond.), 227, 13581 fig., 9 refs

\section{Immunogenicity and Specificity of Collagen}

VIII. Studies on the Antigenic Structures of Soluble Fish Collagen WolfF, I., Wick, G., FurThMaYR, H., TimPL, R., and Steffen, C. (1970) Immunology, 18, 8431 fig., 9 refs

IX. Resistance of Different Antigenic Determinants of Calf Collagen to Proteolytic Treatment STEFfen, C., Timpl, R., WolfF, I., and FurThMaYR, H. (1970) Immunology, 18, 8492 figs, 13 refs

Synovial Microvascular Derangement in Rheumatoid Arthritis and Osteoarthritis GoLDIE, I. (1970) Acta orthop. scand., 40, 751

Morphologic and Biochemical Aspects of Experimental Extraosseous Tissue Calcification SeIFERT (1970) Clin. Orthop., 69, 146

\section{Pararheumatic (collagen) diseases}

Vascular Disease in Progressive Systemic Sclerosis (Scleroderma) NoRTON, W. L., and NARDO, J. M. (1970) Ann. intern. Med., 73, 3175 figs, 80 refs

In this review from the Tennessee College of Medicine, Memphis, the authors muster evidence for their belief that systemic sclerosis is initiated by microvascular injury leading to tissue devascularization and fibrosis.
Clinical evidence includes the frequency of telangiectasia and of Raynaud's phenomenon early in the disease. Histological studies only rarely reveal damage to large vessels but small arteries and arterioles frequently show intimal thickening. Glomerular afferent arterioles sometimes show fibrinoid necrosis which by fluorescent staining can be shown to contain fibrin but not albumin or globulin. Capillary abnormalities, notable nail-fold vessel changes and widespread basement membrane thickening visible by electron-microscopy, are constant, even in tissues not showing sclerosis. The authors suggest that these capillary changes cause tissue atrophy and sclerosis.

[A useful review which should be read in full.]

M. WILKINSON

Exchange Autografts of Skin in Lupus Erythematosus Cormane, R. H., and Bruinsma, W. (1970) Ann. clin. Res., 2, 22

The authors, from the Department of Dermatology, University of Amsterdam, review the subject of exchange autografts of the skin in man and discuss important immunofluorescence studies in chronic discoid lupus erythematosus (CDLE) and systemic lupus erythematosus (SLE). By punch-graft technique the authors carried out exchange autografts between clinically normal and abnormal skin in patients with the main categories of lupus erythematosus. The grafts were subsequently removed and examined by immunofluorescent technique.

According to the authors quoted in the discussion on immunofluorescence studies, three main groups of lupus erythematosus are described:

(1) CDLE. (2) SLE. (3) Transitory CDLE.

In CDLE and SLE, the patient's own immunoglobulins (Ig) and complement are present in the dermoepidermal junction of the 'diseased skin'. Further, in SLE, the clinically normal skin shows the presence of Ig in the junctional zone, although this was not so in most cases of CDLE. However, in some cases of CDLE, the presence of Ig was detected in the clinically normal skin. These patients have a tendency to "transition to the form of CDLE with systemic involvement' i.e. 'transitory SLE'.

The authors carried out their punch autografts in twenty patients with LE, six with CDLE, four with transitory CDLE, and ten with 'SLE of different categories'. The punch grafts were removed and examined by immunofluorescent techniques and histology [the latter findings are not discussed]. In CDLE the punch biopsies from the abnormal skin were rejected by the clinically normal skin whereas the affected skin accepted normal skin exchange. In all other categories of lupus erythematosus, the exchange autografts were accepted (with one exception). The authors believe that the acceptance of diseased autografts by the clinically uninvolved skin, where IgG deposits were detected, may be regarded as a phenomenon of enhancement.

o. L. S. SCOT

Autoimmune and Autoaggressive Reactions in the Pathogenesis of Connective Tissue Diseases [In Russian] Beglaryan, A. G., and AzNaURyan, A. V. (1970) Arkh. patol., 32, No. 7, p. 628 figs, 19 refs

(Abstr. Wld Med. (1970), 45, 44) 
Pleural-Fluid Glucose in Systemic Lupus Erythematosus CARR, D. T., Lillington, G. A., and Mayne, J. G. (1970) Mayo. Clin. Proc., 45, 409

Association of Thymoma, Myasthenia, Erythroblastopenic Anaemia, and LE-cells in the Blood in the Same Patient (Association de thymome, myasthénie, anémie par érythroblastopénie, et présence de cellules LE dans le sang chez le même malade) Zoupanos, G., SAEGESSER, F., and SCHNEIDER, Cl. (1970) Schweiz. med. Wschr., 100, 18854 figs, 5 refs

Clinical Significance of the Finding of LE-cells (Über die Klinische Bedeutung des Lupus-erythematodesZell-Befundes bei rheumatoider Arthritis) HeidelmanN, G., SCHEDWILL, K., and BöHME, A. (1970) Z. ges. inn. Med., 25, 8172 figs, 79 refs

Periarteritis Nodosa and Tuberculosis (Periarteritis nodosa und Tuberkulose) Tscherfass, S. M., and Magalif, N. I. (1970) $Z$. Erkr. Atm., 132, 1634 figs, 38 refs

Polyarteritis Nodosa with Marked Hepatic and Pancreatic Involvement and with Diabetic Syndrome [In Czech] FučIK, J., and DorazILová, V. (1970) Vnitřni Lek., 16, 8021 fig., 10 refs

Glomerular Microtubules of Systemic Lupus Erythematosus PINCUS et al. (1970) Lancet, 2, 1058

Psychiatric Manifestations of Systemic Lupus Erythematosus (Les manifestations psychiatriques de la maladie lupique) JulIEN, C. G. (1970) Encéphale, 59, 29186 refs

Respiratory Function in Scleroderma: Methods of Investigation ( $\mathrm{La}$ fonction respiratoire dans la sclérodermie: Méthodes d'exploration) MouLIN, G., BRUNE, J., and Arnaud, A. (1970) Ann. Derm. Syph. (Paris), 97, 375 1 ref

Evolution of Scleroderma in Association with Deep Heteroplasia (Evoluzione della malattia sclerodermica in concomitanza di eteroplasia profonda) BIONDI, C. O., and Ruocco, V. (1970) Rif. med., 84, 10135 refs

Vital Microscopical Observations on the Nail Margin in Dermatomyositis and Progressive Scleroderma (Vitalmikroskopische Verlaufsbeobachtungen am Nagelwall bei Dermatomyositis und progressiver Sklerodermie) Schmoranzer, H. (1970) Z. Haut-u. Geschl.-Kr., 45, 66310 figs, 22 refs

Skin Collagen Content and Thickness in Systemic Sclerosis BLACK, M. M., Botroms, E., and SHUSTER, S. (1970) Brit.J. Derm., 83, 5521 fig., 15 refs

Parotid Sialography in Sjögren's Syndrome Gonzalez, L., MACKEnZIE, A. H., and TARAR, R. A. (1970) Radiology, 97, 913 figs, 8 refs
Gastrointestinal Disease in Sjögren's Syndrome NAIKEN, V. S., and Rachman, R. (1970) J. A. Einstein med. Cent., 18, 825 figs, 11 refs

Polyacrylamide Gel Electrophoretic and Immunochemical Studies on Urinary Proteins in Sjögren's Syndrome, with Special Reference to Tubular Proteinuria SAITO, H., Furuyama, T., Shioj, R., Onodera, S., Sasaki, Y., and Iто, H. (1970) Tohoku J. exp. Med., 101, 2054 figs, 19 refs

Marinesco-Sjögren with Myopathy CHACO, J. (1969) Confin. neurol. (Basel), 31, 3492 figs, 6 refs

\section{Immunology and serology}

Antibodies against Neurons in a Patient with Systemic Lupus Erythematosus, Cerebral Palsy, and Epilepsy DiederichSen, H., and PyNDT, I. C. (1970) Brain, 93, 4072 figs, 16 refs

A case of SLE is reported from the City and County Hospital, Odense, Denmark, in which antibodies against neuronal cytoplasm were detected by the indirect immunofluorescence method. The patient was a girl aged 8 years when first seen by the authors. She was mentally retarded, had a slight left spastic hemiplegia, a history of epilepsy, and features suggestive of SLE with a rash on the butterfly area and a positive test for antinuclear factors. As she had been on phenytoin and ethotoin for control of her epilepsy, the SLE was considered to be most probably drug-induced. The antineuron antibody was organ-specific and resistant to both RNase and DNase.

A study of eleven other cases of SLE, including one with neurological symptoms, and 24 other cases of epilepsy failed to reveal any further example with a positive reaction for antineuron antibodies.

In view of the dual nature of this patient's disease no conclusion is drawn concerning the relationship of the antineuron antibody to SLE.

L. E. GLYNN

Kappa: Lambda Light Chain Ratio in IgG eluted from Rheumatoid Arthritis Synovium LINDSTRÖM, F. D. (1970) Clin. exp. Immunol., 7, 12 figs, bibl.

The ratio of kappa to lambda light chains in antibody IgG is different from that of the IgG pool of peripheral blood where it is about $2: 1$. This known difference was used by the author to study the IgG eluted from synovial membranes from which unbound serum proteins had been removed. In rheumatoid membranes IgG was found in eluates from most patients but in none of the four osteoarthrosic membranes. In rheumatoid eluates lambda chains predominated in some, kappa chains in others, and in the remainder there was a slight lambda dominance. These results indicate that the bound IgG in rheumatoid synovial membrane is not derived nonspecifically from the immunoglobulin pool but is an antibody, presumably to some unknown local antigen.

J. BALI 
Circulating Rheumatoid and Antinuclear Factors in Asbestos Workers TURner-WARWICK, M., and PARKeS, W. R. (1970) Brit. med. J., 3, 492

A study of sera from eighty unselected patients known to have been exposed to asbestos and who were referred to the Pneumoconiosis Medical Panel in London revealed an incidence of rheumatoid factor of 27 per cent. and of antinuclear factor of 28 per cent.; one or other factor being present in $47 \cdot 5$ per cent.

Clubbing and crepitations and greater degrees of radiological abnormality were associated with the presence of antibodies, but duration of exposure to asbestos showed no such association. Possible reasons for this finding are presented. One possible explanation being investigated further is that those individuals with an inherent tendency to produce antiglobulin and antinuclear factors may react in an abnormal way to inhaled asbestos.

R. GRAHAME

Study of Rubella Haemagglutination Inhibition Antibodies in Rheumatoid Arthritis KACAKI, J. N., BALDUZZI, P. C., and Vaughan, J. H. (1970) Clin. exp. Immunol., 6, 8851 fig., 13 refs

(Abstr. Wld Med. (1970), 45, 41)

Use of Standard Serological Tests for Syphilis in Screening for Auto-immune Connective Tissue Disease. Chronic Biological False-positive Reactions and Anticomplementary Activity [In English] JoHANsson, E. A. Acta derm.-venereol. (Stockh.), 50, 30518 refs

(Abstr. Wld Med. (1970), 45, 44)

Two Anti-inflammatory Components in Antilymphocytic Serum Billingham, M. E. J., Robinson, B. V., and Gaugas, J. M. (1970) Nature (Lond.), 227, 2761 fig., 15 refs

(Abstr. Wld Med. (1970), 45, 1)

Clinical Significance of a Modified Antistreptolysin Titration (Die klinische Wertigkeit einer modifizierten Antistreptolysintiter-Reaktion) KINDLER, U. (1970) Dtsch. med. Wschr., 95, 21155 figs, 32 refs

Serum Protein Changes in Still's Disease, Rheumatoid Arthritis, and Gout Minchin Clarke, H. G., Freeman, T., and Pryse-Phillips, W. E. M. (1970) Brit. J. exp. Path., 51, 441 1 fig., 9 refs

Serum Sulfhydryl Levels and Rheumatoid Factors in Rheumatoid Arthritis KosAKA, S. (1970) Tohoku J. exp. Med., 100, 34910 figs, 20 refs

Studies on the Coagulation and Fibrinolytic Systems in 'Autoimmune' Disease Corrigan, J. J., JR. (1970) Amer. J. Dis. Child., 120, 3241 fig., 40 refs

Complement Fixation by a Two-Component Antibody System: Immunoglobulin $G$ and Immunoglobulin $M$ AntiGlobulin (Rheumatoid Factor) ScHMID, F. R., RorTt, I. M., and RochA, M. J. (1970) J. exp. Med., 132, 673 7 figs, 29 refs
Methods and Critique of Analysis of Antinuclear Factor by the Immunofluorescence Technique (Methode und Kritik der immunfluoreszenztechnischen Analyse anti-: nuklearer Faktoren) BäUMER, A., and BrinkmaNN, A. (1970) $Z$. Rheumaforsch., 29, 2575 figs, 15 refs

Problem of the Speckled Nuclear Reaction in the Immuno- $\frac{\bar{\sigma}}{\bar{c}}$ fluorescent Analysis of Antinuclear Factors (Zum Problem der gesprenkelten Zellkernreaktion bei der immunfluores-@ zenztechnischen Analyse von antinukleären Faktoren) Baumer, A., and Brinkmann, A. (1970) Z. Rheumaforsch., $\vec{\circ}$ 29, 2643 figs, 9 refs

Depression of Synovial Fluid Complement Activity and $\bar{\omega}$ Rheumatoid Factor Positivity HedBerg, H. (1970) Acta med. scand., 188, 4091 fig., 15 refs

\section{Biochemical studies}

Impairment of Collagen and Elastin Crosslinking by ano Amine Oxidase Inhibitor (34948) CHOU, W. S., RUCKER, R. B., Savage, J. E., and O'Dell, B. L. (1970) Proc. Soc. exp. Biol. (N. Y.), 134, 10782 figs, 20 refs

Investigation into the Distribution and Excretion of Tritiated Hydroxyproline and Proline in the Experimental $\vec{\theta}$ Animal (Tierexperimentelle Untersuchungen über die $-\longrightarrow$ Verteilung und Ausscheidung von tritiummarkeirtem $\square$ Hydroxyprolin und Prolin) MAREK, H., КоCH, H., 응 and Emmrich, R. (1970) Z. ges. inn. Med., 25, 8307 refs

Immunochemical Investigations in Families of Patients with Psoriatic Arthritis and Psoriatic Spondylarthritis (Intrafamiliäre immunochemische Untersuchung bei $\overrightarrow{\vec{O}}$ Psoriasis-Arthritis und Psoriasis-Spondylarthritis) Theiss, B., Schnyder, U. W., and BöNI, A. (1970) Arch. klin. exp. Derm., 239, 701 fig., 16 refs

Diffusion of Epsilon Aminocaproic Acid to the Joints Ahlberg, A. (1970) Proc. Soc. exp. Biol. (N.Y.), 134, 9881 fig., 15 refs

Biologic and Immunologic Similarities Between Rat and $\subseteq$ Human Adrenocorticotropin (ACTH) MATSUYAMA et al. (1970) Endocrinology, 87, 756

Amyloid Coronary Artery Disease, Primary Systemic음 Amyloidosis, and Paraproteinemia BARTH et al. (1970) Arch. intern. Med., 126, 627

\section{Therapy}

Xanthine Nephropathy in a Patient with Lymphosarcoma treated with Allopurinol BAND, P. R., SIlverberG, D. S., Henderson, J. F., Ulan, R. A., Wensel, R. H., BANERJEe, T. K., and LitTle, A. S. (1970) New Engl. J. Med., 283, 354

With the exception of patients with the Lesch-Nyhan syndrome (who lack the ability to reconvert oxypurines to their precursors), the theoretical risk of urinary xanthine stone formation has not previously been seen with allopurinal treatment. In the case reported here, a 
23-year-old labourer with a retroperitoneal lymphosarcoma was treated with allopurinol $800 \mathrm{mg}$. daily, and the serum uric acid fell from $13.9 \mathrm{mg} . / 100 \mathrm{ml}$. to normal levels. Pre-treatment 24-hour urinary uric acid was $1372 \mathrm{mg}$.; 4 days later vincristine $4 \mathrm{mg}$. and cyclophosphamide $2 \mathrm{~g}$. were administered as single intravenous doses, and 3 days after this the patient died. At autopsy a large number of small calculi were found in the renal parenchyma and pelvis. Analysis of a $5 \cdot 3 \mathrm{mg}$. stone showed it to be 85 per cent. xanthine. The development of xanthine stones appeared to be related to the administration of high doses of chemotherapeutic agents at a time when uric acid formation was inhibited by allopurinol.

J. T. SCOTT

Penetration of Clindamycin into Synovial Fluid PlotT, M. A., and Roth, H. (1970) Clin. Pharmacol. Ther., 11, 5771 fig., 8 refs

The purpose of this study from Georgetown University, Washington, D.C., was to determine whether clindamycin (7-chloro-7-deoxylincomycin), penetrates the joint cavity after oral administration in adequate concentrations to treat septic arthritis.

Fifteen patients with joint effusions none of whom had received antibiotic therapy for the previous 2 weeks were each given a single oral dose of 150 to $300 \mathrm{mg}$. clindamycin. Serum and synovial fluid samples were taken before and at various intervals after the dose and were assayed for clindamycin using the cylinder plate technique with Sarcina lutea (ATCC 9341) as the assay organism. Assays were carried out at the Clinical Research Laboratories of the Upjohn Company.

Peak serum levels were obtained 1 hour after the oral dose in most subjects, and after 2 hours in two of them. Significant levels persisted for at least 4 hours. Therapeutically effective levels were also found in synovial fluid in nearly all cases within the first few hours. There were considerable variations from subject to subject, but these did not appear to correlate with the degree of joint inflammation.

The authors conclude that orally-administered clindamycin would be effective in septic arthritis caused by susceptible organisms.

J. R. DALY

Plasma Salicylate Levels in Rheumatoid Arthritis produced by Four Different Salicylate Preparations ARMSTRONG, B. K., UKICH, A. W., and GoAtCher, P. M. (1970) Med. J. Aust., 2, 181

In this report from the Royal Perth Hospital, Australia, plasma salicylate levels were compared after the administration of approximately $3 \mathrm{~g}$./day in divided doses of aloxiprin, soluble calcium aspirin, enteric-coated sodium salicylate (4 doses daily), and a new aspirin-sustained release aspirin combination ('Biprin': Boots Pure Drug Co.) ( 2 doses daily). The plasma salicylate values were lower after aloxiprin, but the new product failed to produce higher or more sustained salicylate levels than the other preparations. The new drug did not appear to have any advantage over established programmes of therapy. The need for tailoring the dose of aspirin in each patient so that adequate plasma salicylate levels are achieved is again emphasized.

A. G. MOWAT
Benign Intracranial Hypertension following Corticosteroid Withdrawal in Childhood Neville, B. G. R., and Wilson, J. (1970) Brit. med. J., 3, 55419 refs (Abstr. Wld Med. (1970), 45, 59)

Interaction between Aspirin and Indomethacin in the Treatment of Rheumatoid Arthritis JEREMY, R., and Towson, J. (1970) Med. J. Aust., 2, 1273 figs, 5 refs (Abstr. Wld Med. (1970), 45, 41)

Basal and Histamine-stimulated Human Gastric Acid Secretion. Lack of Effect of Indomethacin in Therapeutic Doses Winship, D. H., and Bernhard, G. C. (1970) Gastroenterology, 58, 76212 refs

(Abstr. Wld Med. (1970), 45, 7)

Anti-inflammatory Effect of the Trypsin-Kallikrein Inhibitor in Acute Arthritis induced by Urate Crystals in Rabbits SPILberG, I., and Osterland, C. K. (1970) J. Lab. clin. Med., 76, 4722 figs, 29 refs

Studies of the Anti-inflammatory Effect of Fibrinolysis Inhibitors (Untersuchungen zur antiphlogistischen Wirkung von Fibrinolyseinhibitoren) FEYEN, H., NISSEN, H., RASCHE, H., and HiEmeyer, V. (1970) Z. Rheumaforsch., 29, 2763 figs, 46 refs

Effect of Glyvenol on the Inflammation Reaction (Zur wirkung von Glyvenol auf Entzündungsreaktionen) WAGNER, H., JuNGe-HülSING, G., WIRTH, W., and Hauss, W. H. (1970) Z. Rheumaforsch., 29, 2865 figs, 18 refs

Clinical Trial of Arlef (Flufenamic Acid) in the Treatment of Rheumatoid and Osteoarthritis COLLER, P. E. VAN (1970) Med. Proc., 16, 340

Chlorambucil in the Immuno-depressive Treatment of Rheumatoid Arthritis (Le chlorambucil dans le cadre du traitement des polyarthrites rhumatoïdes par les immunodépresseurs) Verhaeghe, A., Delcambre, B., Lesage, R., Derreumaux, L. L., and Cardon, A. (1970) Lille méd., 15, 89321 refs

Effects of Chlorambucil (Leukeran) Treatment in Rheumatoid Arthritis Stroescu, O., and Stroescu, V. (1970) Rev. roum. Méd. interne, 7, 36913 refs

Experience with a Combination of Oxyphenbutazone (Tanderil) and Prednisolone in Painful Affections of the Locomotor System (Erfahrungen mit einer Kombination von Oxyphenbutazon und Prednisolon bei schmerzhaften Erkrankungen des Bewegungsapparates) GRIMMEISEN, H. (1970) Med. Mschr., 24, 4224 refs

Injections and Local Infiltrations of Triamcinolone Hexacetonide in Rheumatology (Inyecciones $e$ infiltraciones locales de triamcinolona hexacetonide (Lederle) en reumatologia) UsobIAGA, J. L. DE (1970) Rev. esp. Reum., 13, 3498 refs

Synovial pH in Rheumatoid Knee Joints. II. The Effect of Local Corticosteroid Treatment GoLDIE and HACHEMSON (1970) Acta orthop. scand., 41, 354

Salicylate-induced Hypoprothrombinemia FAUSA, $O$. (1970) Acta med. scand., 188, 4034 figs, 28 refs 
Aspirin: Intestinal Damage in Rats BRODIE et al. (1970) Science, 170, 183

\section{Surgery}

Intramedullary Blood Flow Through Arthrodesis-Treated Joints LemperG, R. K., and ARnoldi, C. C. (1970) Angiology, 21, 3685 figs, 9 refs

The importance of intramedullary blood flow in restoring the circulation after limb severance was investigated using rabbits

A complete transection of knee joint was performed leaving the popliteal artery intact. The joint surfaces of femur and tibia were removed to leave flat cancellous bone surfaces which were then fixed in exact approximation by screwing. All veins were ligated.

Angiography showed that the flow of blood from tibia to the intramedullary vessels of femur took place via the arthrodesis from $20 \mathrm{~min}$. to $3 \mathrm{hrs}$ after the completion of the experiment. Longer observations were not undertaken.

It is suggested that, in cases of traumatic amputation of a limb at the level of a joint in which re-establishment of soft tissue drainage is unlikely, arthrodesis may contribute to the saving of the extremity. Success is more likely in the peripheral parts of the limb when the capacity of the transmedullary drainage stands in reasonable proportion to the arterial flow.

P. J. L. HOLT

Surgical Relief for Spastic Tetraplegia due to Cervical Cord Compression Fuller, D. J. (1970) J. Bone Jt Surg., 52-B, 4654 figs, 4 refs

This paper from Southampton describes an unusual but treatable cause of spastic tetraparesis secondary to a congenital anomaly of the cervical spine.

A man aged 42 years first noticed weakness of the right leg during adolescence. Deterioration was gradual. Eventually all four limbs exhibited spastic paresis with severe clonus of the right ankle and wrist. Radiographs of the cervical spine revealed a bony mass deep to the laminae of the axis, causing a reduction in the capacity of the cervical canal.

Operative removal of the laminae of $C_{2}$ and $C_{3}$ and the anomalous bone led to a rapid improvement of his symptoms. The power of both lower limbs increased, and the spontaneous clonus decreased.

The author emphasizes the importance of the awareness of such treatable causes of spastic tetraparesis and the undertaking of adequate radiographic studies of the cervical spine.

A. R. TAYLOR

Vascular Sequelae of Experimental Osteotomy BROOKEs, M., Richards, D. J., and Singh, M. (1970) Angiology, 21, 35513 figs, 25 refs

This paper, from the Department of Anatomy and Orthopaedic Surgery at Guy's Hospital, investigates the effects of experimental osteotomy at the surgical neck of the adult rabbit humerus. At the healing fracture site, bone formation was studied histologically and vascular patterns by microangiography; intra-bone mixed blood and tissue fluid pH was also measured. An indirect method involving arteriolar blockage by radioactive particles was used to monitor blood flow rates in the whole forelimb skeleton, at the fracture site and in the $\square$ head of the humerus. During the first post-operative month, considerable spongy bone deposition occurred in $\vec{F}$ the profusely vascular fracture site, where the $\mathrm{pH}$ and $\stackrel{9}{9}$ blood flow rate were both higher than on the unoperated 0 contralateral side. In the second month a compact bony 흠 cortex and marrow cavity were reformed. While spongy $\frac{\bar{\sigma}}{T}$ bone was being replaced by compact bone, the vascularity $₫$ and blood pH gradually diminished and the blood flow rate fell precipitately below that of the contralateral side. $\%$ Subsequently blood $\mathrm{pH}$ fell below and flow rate remained $\vec{\circ}$ below the corresponding values of the unoperated side. The authors comment on the possible relevance of the $\vec{\omega}$ elevated flow rate in the isolated humeral head to the beneficial effect of osteotomy in osteoarthrosis. The $\frac{\bar{\alpha}}{2}$ increased flow rate in the humeral head does not, however, appear to differ from that in the whole limb skeleton. R. A. STOCKWELL

Total Hip Replacement-The Past, Present, and Future Sheehan, J. M. (1970) J. Irish med. Ass., 63, 40312 工 figs, 7 refs

Present State of the Surgery of Arthrosis and the Peripheral $\frac{\partial}{\frac{\partial}{\partial}}$ Joints (Estado actual de la cirugia de las artrosis en las articulaciones periféricas) POAL-MANRESA, J., and $\vec{\varphi}$

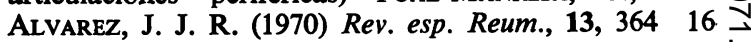
figs, 26 refs

Surgery in Rheumatoid Arthritis MoHANDAs, N. (1970) Antiseptic, 67, 43215 refs

Autogenous Whole-Joint Replacement: the Efifect of the $\frac{\mathrm{Q}}{\mathrm{Q}}$ Capsule KeTtLeKAMP et al. (1970) Clin. Orthop., 69, 271

\section{Other general subjects}

Pathology of the Kidney in Waldenström's Macroglobulinemia. Study of Sixteen Cases Morel-Maroger, $\bar{\varrho}$ L., Basch, A., Danon, F., Verroust, P., and Richet, G. (1970) New Engl. J. Med., 283, 1234 figs, 28 refs (Abstr. Wld Med. (1970), 45, 4)

Suprapatellar Effusions. A New Diagnostic Sign HARRIS, R. D., and Hechт, H. L. (1970) Radiology, 97, 16 figs, 6 refs

Costen's Syndrome (A propósito del sindrome de Costen) VAlverde, J., Brito, M., and Barceló, P. (1970) Rev. esp. Reum., 13, 36014 refs

Skin Clues in the Diagnosis of Rheumatism and Arthritis $\mathrm{\omega}$ GoRDON, W. (1970) S. Afr. med. J., 44, 1186

Endocrine Rheumatism (Reumatismos endocrinos) BorraChero, J. (1970) Rev. esp. Reum., 13, 331

Arthralgia-Purpura-Weakness-Cryoglobulinemia LAPES, M. J., and DAVIS, J. S. (1970) Arch. intern. Med., 126, 287 13 refs

Rheumatoid Cyst causing Extradural Compression. A $气$ Case Report LINQUisT and MCDONNELl (1970) J. Bone Jt Surg., 52A, 1235 